\title{
SUSTAINABLE CAREER DEVELOPMENT OF THE SENIOR HIGH SCHOOL EDUCATORS
}

\author{
Milka \\ Universitas Kristen Indonesia Toraja \\ Email: milkachery77@gmail.com \\ Nurul Ulfatin; Bambang Budi Wiyono; Imron Arifin \\ Universitas Negeri Malang
}

\begin{abstract}
This paper aimed to describe how educators explore their career to achieve the goals which have been set beforehand. It also attempted to provide a clear image of different career strategies which have been implemented by the educators at schools. This study used qualitative approach by employing the multi-case study design. Data was analyzed using the constant comparative method. The result indicated some differences were found at the stage of career exploration. Furthermore, at the stage of determination of career goals, the educators had been determined to commit to their organizational or professional growth.
\end{abstract}

Keywords: career development, educators, career exploration, career goals, career strategies.

\section{INTRODUCTION}

Every individual including educators is fully responsible for their own career although they have their parents or other people as their role model (Korsakiene \& Smaliukiene, 2014; Nazli, 2007). Educators in career selection, for sure, are encouraged by three key factors that are intrinsic, extrinsic, and altruistic (Bakar et.al, 2014; Khan, 2003; Yu“ce, et al., 2013; Claudia, 2015). The advanced development of education depends on the qualification and ability of the educators in promoting learners' potentials. Therefore, the educators need to work together with educational organizations to improve their knowledge, skills, and competence that will result in their better performance in advancing schools (McDonald \& Hite, 2005; Yarnall, 2008). In other words, the educators need to work on their career development. The general purposes of the educator's career development are to promote the educators competence and develop their career as professionals. This career development is expected to bring impacts on their welfare (Sudjana, 2006).

Career development emphasized in this study was of junior as well as senior educators. Junior educators or the freshmen need an assistance in developing their self-awareness in order that they can persist in the educational career (Wilson \&
Deaney, 2010). There has not been researching conducted to discuss efforts in developing the career of educators in the Indonesian context. This study, thus, is crucial since other researchers are more likely to develop an interest in reviewing career development strategies; among which is Okumura \& Miller (2010) who conducted a study on immigrant Japanese teachers. They were finally able to underline some strategies used by the immigrant Japanese teachers in New Zealand: exploring teaching as a career path, gaining appropriate qualifications, finding a job, and maintaining satisfaction. These strategies were proved effective for them to keep Confucianism cultural values and at the same time pursue their practitioner career based on Kong $\mathrm{Hu} \mathrm{Cu}$ teachings. Another research finding by Creed \& Hughes (2012) highlighted that career compromise was correlated with career development strategies used by the university students in Australia. The career compromise was one of the important aspects in determining their future career. The result of this study contributed to our understanding of career development. None of them, however, is related to the concept of educators career development in the Indonesian context.

This study aimed to describe how educators explore their career to achieve the goals which 
have been set beforehand. Besides, this study also attempted to provide a clear image of different career strategies which have been implemented by the educators at schools. Overall, the present study was mainly focused on three aspects to picture the educators' efforts in sustaining their career. According to Noe (1996), career development requires individuals who are able to understand the needs to seek for knowledge, achievement, skills, and personal objectives through: (1) career exploration, (2) career goals determination, and (3) career strategies implementation.

Career exploration refers to all activities that are conducted by individuals to improve their knowledge and awareness of self and of career environment which are available to help them identify their career development throughout the time (Taveira \& Moreno, 2003; Greenhaus \& Callanan, 2006; Cheung \& Arnold, 2014; Studer, 2015). Self-awareness coined here means that the individuals are able to recognize their talents, interests, skills, strengths, and weaknesses. Meanwhile, having knowledge of environment means being fully informed about career and all individuals who have succeeded to pursue the career (Greenhaus \& Callanan, 2006). From this perspective, there are two definitions of career exploration that can be concluded: (1) career exploration is an effort to look for information related to career problem solving and (2) career exploration is perceived as a lifelong process of learning career and its development (Luzzo \& McGregor, 2001; Taveira \& Moreno, 2003). The explanation clearly shows that there are three aspects covered in career exploration that are self-exploration, environment exploration, and the number of information obtained (Stumpt et. al, 1984). Furthermore, Strom et.al (2014) adds some more items to it, including (a) factors considered to decide on a career path, (b) family and relatives influence on career selection, (c) sources who may prefer talking about career, (d) things you imagine to do for the career, (e) steps to find out about jobs, (f) education level required for the career, $(\mathrm{g})$ friends and relatives career advice, (h) career changes that may occur, (i) the frequency of thinking about the career, (j) school involvement in educators career development, (k) methods to learn about jobs, (l) stress counted during career exploration, (m) degree of certainty of career preference and (n) demography (class, gender, ethnic, and age). Simply, Stumpt, Colarelli, and Hartman (in Noe, 1996) state that career exploration consists of four components which include: (1) where one explores (environment vs self), (2) how one explores (intended vs systematic), (3) how much one explores (frequency and amount of information), and (4) what one explores (the focus of the exploration).

Goal setting theory assumes that human behaviours are goals; the setting of the goals is a process of developing the plans, getting involved in achieving the goals, and evaluating the results (Creed \& Hughes, 2012; Locke \& Latham, 2006). Greenhaus et. al (2000) define career goals as every individual's desires to not only dream but also work hard to accomplish the goals. Career goals are related to outcomes which someone wants to achieve such as promotion, salary increase, and skill improvement. According to Greenhaus \& Callanan (2006), career strategies are behaviours, activities, or experiences which are designed to assist someone to achieve career goals. They assert that someone who carries out a particular career strategy is the one who expects to gain individual as well as professional success. The individual and professional careers are influenced by a number of factors including the nature of the jobs, kinds of jobs, organizational culture, and organizational norms.

\section{METHOD}

This study was approached qualitatively by employing a multi-case study design. This design was selected since this study was going to compare the career development efforts of educators from three different senior high schools found in Makassar, South Sulawesi, Indonesia. The three schools were: SMA Negeri 17, SMA Islam Athirah Kajaolaliddo, and SMA Negeri 1 Makassar. The research sites had distinctive conditions and characteristics which made it possible to carry out a multi-case study there. Table 1 depicts the difference between the three schools.

Informants were selected based on the length of service, career experiences, achievements, and other educational qualifications. It was done to 
Table 1 The Different Characteristics of Research Settings

\begin{tabular}{|c|c|c|c|c|}
\hline No & Components & $\begin{array}{c}\text { SMA Negeri } 17 \\
\text { Makassar }\end{array}$ & $\begin{array}{c}\text { SMA Islam Athirah } \\
\text { Kajaolaiddo }\end{array}$ & $\begin{array}{l}\text { SMA Negeri } 1 \\
\text { Makassar }\end{array}$ \\
\hline 1. & School Status & public school (superior) & $\begin{array}{l}\text { Private school supported } \\
\text { by Yayasan Athirah } \\
\text { (Athirah Foundation) }\end{array}$ & $\begin{array}{l}\text { Public school } \\
\text { (favorite) }\end{array}$ \\
\hline 2. & Accredited Status & $\begin{array}{l}\text { A by final score of } \\
98,00\end{array}$ & A by final score of 97,03 & $\begin{array}{l}\text { A by final score of } \\
96,46\end{array}$ \\
\hline 3. & $\begin{array}{l}\text { Status of the } \\
\text { Educators }\end{array}$ & $\begin{array}{l}\text { PNS (civil servants) } \\
\text { and GTT (part-timers) }\end{array}$ & $\begin{array}{l}\text { Contract teachers, } \\
\text { teachers delegation from } \\
\text { the foundation, and } \\
\text { seconded PNS teachers } \\
\text { (DPK) }\end{array}$ & PNS and GTT \\
\hline 4. & $\begin{array}{l}\text { Qualification of the } \\
\text { Teachers }\end{array}$ & Bachelors and Masters & Bachelors and Masters & $\begin{array}{l}\text { Bachelors and Masters } \\
\text { and Doctors }\end{array}$ \\
\hline 5. & $\begin{array}{l}\text { Functional Position } \\
\text { Policy }\end{array}$ & $\begin{array}{l}\text { Ministerial Regulation } \\
\text { PAN \& RB No. } \\
\text { 16/2009 }\end{array}$ & $\begin{array}{l}\text { Ministerial Decree on } \\
\text { the Utilization of State } \\
\text { Apparatus No. } 84 / 1993\end{array}$ & $\begin{array}{l}\text { Ministerial Regulation } \\
\text { PAN \& RB No. } \\
16 / 2009\end{array}$ \\
\hline 6. & $\begin{array}{l}\text { Freshmen } \\
\text { Recruitment }\end{array}$ & $\begin{array}{l}\text { Selected through the } \\
\text { highest score of an } \\
\text { online test }\end{array}$ & $\begin{array}{l}\text { Selected through a written } \\
\text { test, an interview, and } \\
\text { Koran reading }\end{array}$ & $\begin{array}{l}\text { Selected through an } \\
\text { online test }\end{array}$ \\
\hline 7. & Policymakers & $\begin{array}{l}\text { Head of Education } \\
\text { Office and the principal }\end{array}$ & $\begin{array}{l}\text { Director and the Head } \\
\text { of Human Resources } \\
\text { Division }\end{array}$ & $\begin{array}{l}\text { Head of Education } \\
\text { Office and the } \\
\text { principal }\end{array}$ \\
\hline
\end{tabular}

obtain accurate data relevant to the problem of this research. Further detailed information on the informants is presented in Table 2.

Data was collected through in-depth interviews, observations, and documentation. The informants were allowed to freely express their opinions and feelings. The interview questions did not follow any certain structure, but were outlined based on the focus of the research that was the efforts in sustaining educators career development.

The observation was conducted to investigate the activities of the educators, including their activities when attending the Flag Ceremony, seminar, training, intern MGMP (Association of Subject Teachers), and many others. This observation was useful for the researcher to obtain complete and perceptive data and also to recognize the meaning of every apparent behaviour. It was begun with conducting a descriptive observation which attempted to describe the social situation in general. Then, after recording and analyzing the primary data, the researchers would narrow down the scope of data collection by conducting a focused observation. The next thing to do was to do a selective observation until the final data collection process.

Documentation technique was also employed by the researchers to complement data obtained from the interviews and observations. Data which was collected in the form of documents and archives included: (1) the list of the teachers and staff status, (2) the school's profile, (3) the School Activity Plan (RKS), (4) the school accredited documents, (5) the teachers master documents, (6) the facilities and infrastructure documents, (7) the quality documents, (8) the training, seminar, and/or workshop certificates, (9) the data of teachers rank, (10) the personnel regulations at Perguruan Islam Athirah, (11) the performance assessment forms, (12) the Human Resources Division work programs, (13) the job descriptions and the specification of leadership 
Table 2. Research Informants

\begin{tabular}{|c|c|c|c|c|}
\hline \multirow{2}{*}{ No } & \multirow{2}{*}{ Source of the Informants } & \multicolumn{3}{|c|}{ Number of Informants } \\
\hline & & SMAN 17 & SMA Islam Athirah & SMAN 1 \\
\hline & Teacher/Educator & 3 & 4 & 4 \\
\hline 2. & Principal & 1 & 1 & 1 \\
\hline 3. & Vice Principal & 4 & 2 & 3 \\
\hline 4. & Head of Human Resources Division & - & 1 & - \\
\hline & Staff of the Education Office & & 1 & \\
\hline & $\begin{array}{c}\text { Total } \\
\end{array}$ & 8 & 9 & 8 \\
\hline
\end{tabular}

position, (14) the Revenue and Expenditure Budget, (15) the Decree on teachers assignments, and (16) the guidebook of SMA Islam Athirah Kajaolaliddo. The researchers analyzed all documents related to the focus of the research.

Process Analysis

The data of this multi-case study was analyzed by the constant comparative method. It was conducted through two stages of data analysis, including the individual case and cross-case analysis (Miles et.al., 2014; Bogdan, 1998). The individual case data were analyzed with the interactive model cycle which consists of three activities performed simultaneously; they are data condensation, data presentation, and data verification (Miles et.al., 2014). Data condensation refers to the process of selecting, simplifying, and transforming rough data which has been recorded in the field notes. This activity was conducted by the researchers to develop the theme, generate categories, code the data, and write an analytic note. Data which had been recorded in the field notes (transcripts) was summarized based on the focus of the research. Every topic was coded in order that every piece of the data obtained from the transcripts could be well organized. There were three types of the coding system employed as follows: interviews code (e.g. W.AB.A1.017), documents code (e.g. D.ATH.01.2015), and observations code (e.g. O.01.01.2015).

The researchers also presented the data with data tabulation technique, that is by classifying the data based on the determined categories. The systematically organized data would help the researchers to review the data and make a careful decision on data condensation or data exploration. The temporary conclusion is usually made by the researchers during the process of collecting the data. Therefore, the data can also be verified at that time. There were two ways recognized to verify the data, including (1) unstructured interviews conducted with the key informants and (2) verification of the result of data categorization and synthesis. The data was verified and synthesized by two educators from SMA Negeri 1 Makassar (Drs. Muh. Basri, M.Pd. and Dra. Arum D. Tjondrowati, M.Pd.), head of Human Resources from Islamic School of Athirah (Drs. Yauri M. Idrus, S.Pd.), and two educators from SMA Negeri 17 Makassar (Drs. Abu Hanafi, MM. and Drs. H. Nasrullah, MM.)

This data verification resulted in high data credibility. Thus, the next step to do by the researchers was to draw a temporary conclusion on every research subject by repeatedly doing data reduction until final conclusion or proposition could be made. The conclusion drawn on each subject would be combined and formulated in cross-case research data. As a result, the similarity and the difference in the implementation of educators career development could be detected.

The results of data analysis would be arranged into a temporary conclusion. However, the further check was still needed to ensure whether the researchers had to move to another step or had to revisit the previous steps. Crosscase data analysis was conducted through three stages as follows. The first was to compare and combine all cross-case findings. At this stage, it was necessary to discuss related theories and previous research findings. The second step was to organize conceptual findings related to educators career exploration, career goals, and career strategies implementation. The last step was to develop substantive theories. The crosscase proposition occurred at the second and the third stage. 


\section{RESULTS}

The results of this study indicated that the educators explored their career by (1) showing their ability/achievement, (2) being discipline, (3) working autonomously, (4) showing persistence in reading books, (5) showing skills in teaching, (6) performing good behaviours, (7) showing courage to speak in front of many people, (8) becoming reliable, (9) showing high curiosity, (10) being always willing to sign up for various activities, and (11) not procrastinating. The eleven aspects of career exploration have covered self-exploration (number 1, 2, 3, 4, 5, 6, 7 ) and exploration of the environment (number $8,9,10,11)$.

At the first year working at the schools, the educators mostly showed self-exploration instead of the exploration of the environment. This occurred due to family influence on career selection, particularly of the women's.

I chose IKIP Makassar (now Universitas Negeri Makassar) for my family, especially my mother said that as a Buginese woman, I need to pay more attention to my family when I get married. Therefore, being a teacher can be very efficient in saving my time so that I can spend more time with my family. (W.KS.B11.ATH)

Meanwhile, career selection of the male teachers was dominantly affected by the desire to perform their potentials in ability in their field of interest.

Why did I choose "physical education"? first, because I love the sport. second, I was obsessed with the figure of my physical teacher when I was in high school. The teacher was popular among the students as a strict but lovable teacher. As a result, I preferred to go to the Faculty of Sport and Physical Education in Universitas Negeri Makassar (UNM). (W.BY.B11.ATH)

Career exploration was also different for the educators at every stage. At the preservice stage, the educators were wondering whether they were going to continue their career as a teacher or not. At this stage, career exploration had not yet existed since the educators were still pursuing their bachelor degree. Entering the first year of the early service stage, the educators started to explore themselves by being discipline, showing the ability to work or achievement, performing good behaviours, showing courage to speak in front of many people, and being curious about the job.

I was trying to be loyal to the supervisor by showing the best performance such as being fully responsible for my job. Then, I was trying to be disciplined. A school will be determined good if the teachers are able to teach according to learning materials. Are the learning materials used as guidance to teach so that the goals can be achieved? Teachers' career is supported by their achievement. (W.MS.C1.17)

Meanwhile, at the long-term career service stage which was mostly experienced by the teachers who had been working for about 5 years, self-exploration and exploration of the environment were done by keeping the trust given by the leader, showing high curiosity, being willing to represent the school, and not procrastinating.

I have been always curious since a long time ago, and I will not feel ashamed even if someone thinks I do not know. Sometimes, people laugh at me because I do not know a thing but I do not care. In fact, it is actually my strength...now I have been appointed to be an instructor. I want to improve myself and am willing to share my knowledge with others.(W.AR.C1.01)

The educator's career goals refer to their commitment to the institution or to their profession. We found out that the educators had four career goals that are: (1) to be a professional teacher/educator, (2) to keep being satisfied/ contented, (3) to contribute to the school success, and (4) to get another structural assignment. One of the goals was described by one of the informants as follows.

I think we should value teachers/educators because they are willing to educate our children and also contribute to the development of the country. Also, in the afterlife, the educators will be rewarded for they have shared their knowledge with others. So, it means a lot to me to be a teacher. I will be very happy if I can make the students able to do the task assigned to them. (W.GN.C2.ATH)

Findings on career strategies which were implemented by the teachers at schools cannot be separated from the career goals. Some of the career strategies include (1) working overtime, (2) attempting to build a relationship with other 
educators in educational organizations, (3) attempting to finding out about the desired work, (4) attempting to make the supervisor care about aspiration and career goals, (5) attempting to be a role model in the society, and (6) attempting to make the supervisor care about achievement at work.

I have no idea when my career will reach its peak, I hope it is not yet there. I still enjoy teaching as always because teaching is my duty. Even if I am selected as a principal, I think I am still able to run the position. However, I am calm, not burdened with any additional task, or even with teaching activities. Most of the time, I come early to school and come home late since this is a part of the coaching process. (W.MB.C3.01)

Those career strategies were demonstrated naturally since the educators were aware of their main duties and functions as an educator. They usually performed these behaviours in the early five years of teaching experience. Nevertheless, the orientation would be soon changed at the next five year period (service career stage).

\section{DISCUSSION}

Our findings have confirmed and expanded the results of the previous studies related to attempts to sustain educators' career, which can be done through career exploration, determination of career goals, and implementation of career strategies.

\section{Career Exploration}

Career exploration shown by the educators at schools consist of self-exploration (number 1-7) and exploration of the environment (number 8-11). During self-exploration, the educators were influenced by their personality traits such as the desire to experience new things, and to be well informed about themselves (including ideas and values embraced by the individuals). This finding supports the research by Purwanto (2012) which suggested that personality had an effect on junior high school students career exploration. Furthermore, Greenhaus \& Sklarew (1981) also state that self-exploration is related to jobs. Selfexploration has a positive correlation with the satisfaction of the students with low level of anxiety. It, however, is negatively correlated with the satisfaction of the students with high level of anxiety

When exploring the environment, the educators tended to seek for information related to the additional task (position/rank) together with its rank specification. Equipped with information, the educators could arrange strategies to improve their performance. This finding advocates the results of the research conducted by Stumpt et.al (1984) who state that exploration of the environment and the number of information obtained are significantly correlated with performance and interviews results. Self-exploration refers to the exploration of every individual's needs, values, and experiences which reflect their career choices and to reflect their awareness of self. Meanwhile, exploration of the environment involves every individual to collect information about jobs, organizations, or industries relevant to their career selection (Zikic \& Klehe,2006; Greenhaus \& Callanan, 2006).

The educators explored the environment in order to evaluate themselves and improve their performance particularly when they were assigned a new role. The self-evaluation means to question self about talents, interests, strengths, and weaknesses relevant to the recent career. This finding supports the research findings by Wiyono (2017) who found out that self-evaluation of principal transformational leadership style affected teachers' motivation and school's performance indirectly.

\section{Setting Career Goals}

The educators at school had not received any training on career planning. However, some of them had seemingly committed to their organization and also their profession. As said by Pace et.al (1991), there are two kinds of career, institutional and professional. Sometimes, in the workplace, people need to realize the elements of institutional and professional career. In addition, the educators also have the freedom to decide the form of their commitment.

Our findings showed that the educators had set their institutional and professional career goals. The formulation of the institutional goals covered: to be able to contribute to the school's success, and to receive an additional assignment (structural). Meanwhile, their professional career 
goals were formulated as follows: to become a professional educator and to keep being satisfied/ contented with teaching. By setting the goals, an educator does not need to target a certain job. On the other hand, she/he can work to achieve the goals and to improve his/her performance (Latham et.al, 2010; Greenhaus \& Callanan, 2006).

In general, the educators at the schools were able to achieve their career goals for some reasons including uniformed work hours (from 07.00 to 15.00), the availability of the educators, and the absence of teachers' resignation. This finding is in contrast with the research findings by Toygar \& Ergun (2012) who investigated the career goals and career opportunities of the nurses in Turkey. They pointed out some reasons for why the nurses could not achieve the goals. The first one is because they were registered to work in shifts. The next one is because there were only a small number of nurses available. The last one is because of the economic problems.

The pre-service Turkish teachers perceived leadership as a different career path from teaching. This is a significant reason that makes us think that in Turkey the educators must serve as qualified teachers prior to promoting their position as the school's leaders. Besides, they also need to fulfill the criteria required for the position through in-service education (Eren, 2012). Similarly, our finding also suggests that the educators who have set their goal to get promoted (such as to be a principal, a vice principal, a vice principal assistant, the head of the laboratory, the head of the division, and director) must meet some criteria including having minimum 4 years of teaching experience and functional rank of Young Teacher, III/c.

The educators career goal to keep the satisfaction/happiness has confirmed the results of the research conducted by Okamura and Miller (2010) who state that to obtain work satisfaction, educators need to take advantages from all available resources including supports from inside or outside the school (teachers networking to share practical information and improve professional skills). Educators need to reset their goals every time they pass a career stage as a feedback. Shi Hu et.al (2016) have discovered the importance of a feedback to career goals, the importance of setting the career goals, and its importance to young people to pursue their career. The feedback which is relevant to the career goals and strategies has a potential to help the people to have more reflection, concern, and feeling of uncertainty toward their future compared to the feedback which is relevant to the career development.

\section{Implementation of Career Strategies}

Career strategies are implemented by educators at every different career stage (Tomlinson et.al, 2012). The educators in their early years of teaching were most likely to perform active behaviours such as establishing friendships at school. It was done to make them familiar with the school culture and the characteristics of the people. Unlike the young educators, the senior educators who had been familiar with the school situation conducted their career strategies by attempting to make the leader care about their aspiration and work achievement. This strategy was known as assimilation strategy. This finding has confirmed the results of the study conducted by Tomlinson et.al (2012) on the assimilation strategy that involved the behaviour and attitudes patterns of young white and black women in England. It was found out that they performed the assimilation strategy through self-presentation.

Based on the findings on three steps of developing educators career, we may come to the conclusion that different career exploration shown by the educators was influenced by the preservice, early service, and career service career stage (Hanson, 2003). Every implementation of any career strategy by the educators at school indicated their commitment and loyalty to the school and the leader. This finding is supported by the research findings on the effectiveness of various career strategies which has proved that various skills and work experiences had a significant effect on an individual's success in pursuing his/her career (Greenhaus \& Callanan, 2006). The idea of educator's career development has seemed to against the problems at the workplace, including the increasing number of unemployment, work termination due to technology advancement, the improvement of compensation gap between skilled and unskilled employees, uneven employment opportunities, and unreliable employees (McDonald \& Hite, 
2005). However, these problems were not found in the present study since this study was focused on sustainable educators' career development.

\section{CONCLUSION AND RECOMMENDATION}

\section{Conclusion}

This article reviews the experiences of the Senior High School educators. The determination of career goals had been adjusted to their commitment to the organization or the profession. Meanwhile, to balance them all, they applied various career strategies which were relevant to the condition of the institution and the profession. By sustaining their career, the educators would be able to improve the availability of the qualified educators at schools. It will certainly bring a great impact to the schools since the educators have been transformed into potential and skilled human resources.

\section{Recommendation}

We realize that this study has some limitations. Therefore, we hope that this can provide an opportunity to other researchers to investigate this issue from different perspectives.

\section{REFERENCES}

Bakar, A.R., et.al. 2014. So You Want To Be A Teacher: What Are You Reason. Journal International Education Studies, 7 (11), 155 161.

Bogdan, R. C \& Biklen, S. K. 1998. Qualitative Research for Education: An Introduction to Theory and Method. Boston: Allyn and Bacon, Inc.

Cheung, R., \& Arnold, J. 2014. The Impact of Career Development Among Hongkong Chinese University Student. Journal of College Student Development, 55 (7), 732748.

Claudia, V. 2015. The Role of Motivation in the Development of School Teachers' Career. Social and Behavioral Science, 180, 11091115.

Creed, P. A., \& Hughes, T. 2012. Career Development Strategies as Moderators between Career Compromise and Career
Outcomes in Emerging Adults. Journal of Career Development, 40 (2), 146-163.

Eren, A. 2012. Perspektive Teachers' Interest in Teaching, Professional Plans about Teaching and Career Choice Satisfaction: A Relevant Framework? Australian Journal of Education, 56 (3), 303-318.

Greenhaus, J. H., \& Callanan, G. A. 2006. Encyclopedia of Career Development. Volume 1. London: Sage Publication. Inc.

Greenhaus, J. H., \& Sklarew, N. D. 1981. Some Sources and Consequences of Career Exploration. Journal of Vocational Behavior, 1(1), 1-12.

Hanson, E. M. 2003. Educational Administration and Organizational Behavior. Fifth Edition. Boston: Pearson Education, Inc.

Khan, W. A. 2003. Teaching Motivation. New Delhi: Discovery Publishing House.

Korsakiene, R., \& Smaliukiene, R. 2014. The Implications of Contemporary Approaches Toward Career Development. Journal Social and Behavioral Science, 109 (1), 422-426.

Latham, G. P., Stajkovic, A. D., \& Locke, E. A. 2010. The Relevance and Viability of Subconscious Goals in the Workplace. Journal of Management, 36 (1), 234-255.

Locke, E. A., \& Latham, G. P. 2006. New Direction in Goal-Setting Theory, Journal Current Directions in Psychological Science, 15 (5), 265-268.

Luzzo, D. A., \& McGregor, M. W. 2001. Practice and Research in Career Counseling and Development, (Online). Journal of Vocational Behavior, 50 (1), 98-139.

McDonald, K. S., \& Hite, L. M. 2005. Reviving The Relevance of Career Development in Human Resource Development. Human Resources Development Review, 4 (4), 418 439.

Miles, M.B, Huberman, A. M., \& Saldana, J. 2014. Qualitative Data Analysis: A Methods Sourcebook (Third Edition). London: Sage Publication, Inc.

Nazli, S. 2007. Career Development in Primary School Children. Career Development International, 12 (5), 446-462.

Noe, R. A. 1996. Is Career Management Related to Employee Development and Performance? Journal of Organizational, 17 (1), 119-133. 
Okamura, Y., \& Miller, J. 2010. Career Development Strategies for Japanese Immigrant Teachers. Australian Journal of Career Development, 19 (3), 33-42.

Pace, R. W., Smith, P. C., \& Mills, G. E. 1991. Human Resources Development. New Jersey: Prentice Hall, Englewood Cliffs.

Purwanto, E. 2012. Factors Affecting Career Exploration of the Junior High School Students, Online, Jurnal Cakrawala Pendidikan, 2 (1), 228-243.

Shi Hu, Hood, M., \& Creed, P. A. 2016. Career Goal Importance as a Moderator in Relationship between Career Feedback and Career-Related Stress. Journal of Career Development. First Published 21 September 2016.

Strom, P. S., Strom, R. D., Whitten, L. S., \& Kraska, M. F. 2014. Adolescent Identity and Career Exploration. NASSP Bulletin, 98 (2), 163-179.

Studer, J. R. 2015. The Profesional School Counselor: An Advocate for Student. Belmont, CA: Thomson Brooks.

Stumpt, S. A., Austin, E. J., \& Harman, K. 1984. The Impact of Career Exploration and Interview Readiness on Interview Performance and Outcomes. Journal of Vocational Behavior, 24 (1), 221-235.

Sudjana, N. 2006. Quality Standards of Supervisors. Jakarta: Depdiknas.

Taveira, M. D. C., \& Moreno, M. L. R. 2003. Guidance Theory and Practice: The Status of Career Exploration. British Journal of Guidance and Counseling, 31(2), 189-207.
Tomlinson, J. et.al. 2012. Structure, Agency and Career Strategies of White women and Black and Minority Ethnic Individuals in The Legal Profession. Journal Human Relations, 66 (2), 246-269.

Toygar, S., \& Ergun, Y.A. (2012). Career Goals of a Private Hospital Nurses and Career Opportunities Offered to Them. Journal Social and Behavioral Sciences, 47 (1), 1668-1674.

Wilson, E., \& Deaney, R. 2010. Changing Career and Changing Identity: How do Teacher Career Changer Exercise Agency in Identity. Social Psychology Education Journal, 13 (1), 169-183.

Wiyono, B. B. 2017. The Effect of Self-evaluation on The Principals' Transformational Leadership, Teachers' Work Motivation, Teamwork Effectiveness, and School Improvement. International Journal of Leadership in Education, 1-21.

Yarnall, J. (2008). Strategic Career Management: Developing Your Talent. New York: Butterworth-Heinemannis an Imprint of Elsevier.

Yüce, K., Esin Y. S., Koc, er, A.O, dan Kana F. 2013. Motivations for Choosing Teaching as a Career: a Perspective of Pre-service Teachers from a Turkish Context. Journal Asia Pacific Education, 14, 295-306.

Zikic, J. \& Klehe, U.C. 2006. Job Loss as a Blessing in Disguise: The Role of Career Exploration and Career Planning in Predicting Reemployment Quality. Journal of Vocational Behavior, 69, 391-409. 